\title{
RAIINSTEK
}

\section{PENGARUH MODEL PEMBELAJARAN PROBLEM BASED LEARNING DISERTAI METODE SCAFFOLDING DAN MOTIVASI BELAJAR TERHADAP PEMAHAMAN KONSEP FISIKA}

\author{
Hilde Gardis Spriani ${ }^{1}$, Nurul Ain ${ }^{2}$, Hestiningtyas Yuli Pratiwi $^{3}$ \\ Pendidikan Fisika, Universitas Kanjuruhan Malang ${ }^{\mathbf{1}, 2,3}$ \\ hildegardisspriani95@gmail.com¹, nurulain@unikama.ac.id ${ }^{2}$, hesti@unikama.ac.id ${ }^{3}$
}

\begin{abstract}
Abstrak. Penelitian ini bertujuan untuk (1) mengetahui perbedaan motivasi belajar siswa yang menggunakan model pembelajaran Problem Based Learning melali metode scaffolding dengan model pembelajaran konvensional; (2) mengetahui perbedaan pemahaman konsep fisika yang menggunakan model pembelajaran Problem Based Learning melalui metode scaffolding dengan model pembelajaran konvensional; (3) mengetahui interaksi antara model pembelajaran Problem Based Learning melalui metode scaffolding dan motivasi belajar terhadap pemahaman konsep fisika. Jenis penelitian yang digunakan adalah quasi eksperimendengan rancangan posttest only control group design. Populasi pada penelitian ini adalah seluruh siswa kelas VIII SMPN I Pakisaji dan sampel penelitian terdiri dari 30 siswa kelas VIII F sebagai kelas kontrol dan 30 siswa kelas VIII G sebagai kelas eksperimen. Teknik pengambilan sampel yang digunakan adalah purposive sampling. Pengambilan data motivasi belajar menggunakan lembar observasi dan tes tertulis untuk pemahaman konsep fisika. Hasil penelitian menunjukkan bahwa (1) adanya perbedaan motivasi belajar siswa yang menggunakan model pembelajaran Problem Based Learning melalui metode scaffolding dengan model pembelajaran konvensional dengan nilai Fhitung > Ftabel $(5,631>4,01)$ pada taraf signifikan 0,05 ; (2) adanya perbedaan pemahaman konsep fisika yang menggunakan model pembelajaran Problem Based Learning melalui metode scaffolding dengan model pembelajaran konvensional denagn nilai Fhitung $>$ Ftabel $(14,03>0,05)$ pada taraf signifikan 0,05; (3) adanya interaksi antara model pembelajaran Problem Based Learning melalui metode scaffolding dan motivasi belajar terhadap pemahaman konsep fisika dengan niali Fhitung > Ftabel $(6,838>4,01)$ pada taraf signifikan 0,05. Dengan demikian dapat disimpulkan bahwa penggunaan model pembelajaran Problem Based Learning melalui metode Scaffolding memberikan dampak yang positif terhadap motivasi belajar dan pemahaman konsep fisika siswa yaitu motivasi dan pemahaman konsep fisika siswa lebih tinggi dibandingkan siswa yang menggunakan model pembelajaran konvensional.
\end{abstract}

Kata Kunci: Problem based learning, scaffolding; motivasi belajar; pemahaman konsep fisika

\section{PENDAHULUAN}

Fisika merupakan satu cabang dari mata pelajaran Ilmu Pengetahuan Alam (IPA) atau sains dan merupakan ilmu yang lahir dan berkembang lewat langkah-langkah observasi, perumusan masalah, penyusunan hipotesis melalui eksperimen, penarikan kesimpilan, serta penemuan teori dan konsep (Trianto, 2011). Dapat dikatakan bahwa hakikat fisika adalah ilmu engetahuan alam yang mempelajari gejala-gejala melalui serangkaian proses yang dikenal dengan proses ilmiah. Berbagai upaya yang telah dilakukan untuk mencapai tujuan embelajaran fisika belum tercapai secara optimal. Secara garis besar siswa menganggap bahwa pelajaran fisika itu tidak menarik dan terlalu sulit karena banyak menghafalkan rumus dan terlalu banyak teori (Umrotun, 2012). Tetapi pada kenyataanya bahwa fisika bukan hanya berisi teori dan rumus saja tetapi bagaimana memahami konsep-konsep fisika. Pemahaman konsep fisika sangat penting karena untuk menjamin hasil belajar yang baik siswa harus memahami konsep materi yang dipelajari. 
Keadaan di lapangan menunjukkan bahwa banyak siswa yang kurang ttermotivasi untuk belajar fisika (Rahman, 2004). Hal ini itunjukkan dengan indikator motivasi belajar yaitu minat siswa dalam mempelajari fisika kurang,siswa kurang kosentrasi dan perhatian pada saat proses pembelajaran, serta siswa kurang tekun dalam mengerjakan soal-soal. Siswa kurang termotivasi untuk belajar fisika karena mereka menganggap bahwa pelajaran fisika itu sangat sulit. Tetapi, jika siswa termotivasi akan mudah diarahkan, diberi penugasan, cendrung memiliki rasa ingin tahu yang besar, aktif dalam mencari informasi tentang materi yang dijelaskan oleh guru serta menggunakan prose kognitif yang lebih tinggi untuk mempelajari dan menyerap pelajaran yang diberikan (Slavin, 2009).

Rendahnya motivasi siswa dalam pembelajaran fisika mengakibatkan prestasi belajar menurun (Krisnawati, 2009). Memberikan motivasi kepa peserta didik berarti menggerakkan siswa untuk melakukan sesuatu (Sardiman, 2010). Oleh karena itu penting menciptakan kondisi tertentu agar siswa selalu termotivasi dan ingin terus belajar. Memandang situasi dan kondisi itu, maka seorang guru yang kreatif harus dapat meningkatkan motivasi belajar siswa dalam mempelajari fisika dengan menggunakan model pembelajaran yang dapat membantu siswa agar termotivasu dalam pelajaran fisika. Jadi, untuk mengantisipasi hal tersebut maka perlu menggunakan model pembelajaran yang aktif. Salah satu model pembelajaran yang mengaktifkan siswa adalah model pembelajaran berbasis masalah atau sering disebut Problem Based Learning (PBL).

Menurut (Akinoglu., \& Tandagon, 2007) PBL merupakan suatu proses embelajaran yang aktif (active learning). Pada pembelajaran yang aktif, kemampuan berpikir kritis siswa dan pemecahan masalah dapat dikembangkan. Dalam proses pembelajaran Problem Based Learning siswa bukan hanya memahami konsep yang sesui dengan masalah yang disajikkan saja melainkan juga harus mendapat pengalaman belajar yang berkaitan dengan pemecahan masalah. Model pembelajaran PBL memiliki kelebihan, namun model PBL juga memiliki kekurangan yang harus diantisipasi oleh guru. Jadi untuk mengantisipasi hal tersebut maka PBL dikombinasi dengan metode scaffolding (Yadav,A., subedi, D., Lunberg, M.A., \& Bunting, 2011). Menurut (Mamin, 2008) bahwa scaffolding merupkan salah satu model pembelajaran yang digunakan oleh guru untuk memberikan bantuan atau dukungan kepada peserta didik pada saat awal proses pembelajaran agar proses pembelajaran dapat berlangsung secara optimal. Model pembelajaran PBL dikombinasi dengan metode scaffolding bertujuan agar dapat membantu siswa mengembangkan kemampuan analisisnya dalam pelajaran Fisika, sehingga dalam proses pembelajaran siswa mendapat bantuan (scaffolding) dari guru.

Dari uraian di atas untuk memperbaiki model pembelajaran Fisika yang digunakan, maka dilakukan penelitian dengan judul : " Pengaruh Model Pembelajaran Problem Based Learning Melalui Metode Scaffolding Dan Motivasi Belajar Terhadap Pemahaman Konsep Fisika Smp “, yang dapat diharapkan mampu meningkatkan motivasi belajar dan pemahaman konsep fisika SMP Negeri I Pakisaji.

\section{METODE PENELITIAN}

Penelitian ini menggunakan jenis penelitian eksperimen semu (Quasi Experimental) dengan desain yang digunakan adalah posttest only control group design seperti yang ditunjukkan pada Tabel 1. Populasi pada penelitian ini adalah siswa kelas VIII SMP Negeri I Pakisaji tahun ajaran 2018/2019 yang terdiri dari 7 kelas dengan jumlah siswa secara keseluruhan adalah 180 siswa. Teknik pengambilan sampel yang digunakan adalah porpusive sampling yaitu kelas VIII F sebagai kelas kontrol dengan jumlah siswa 30 siswa dan kelas VIII G sebagai kelas eksperimen dengan jumlah siswa 30 siswa. 
Teknik pengumpulan data yang digunakan dalam penelitian ini adalah lembar observasi untuk motivasi belajar dan tes tertulis untuk pemahaman konsep. Sebelum soal digunakan dilakukan uji taraf kesukaran, uji daya pembeda, uji validitas, dan uji realibilitas. Pengujian hipotesis dalam penelitian ini menggunakan uji Anova Dua Jalur (Two Way Anova).

Tabel 1 Rancangan Penelitian

\begin{tabular}{llc}
\hline \multicolumn{1}{c}{ Responden } & \multicolumn{1}{c}{ Perlakuan } & Postesst \\
\hline Kelas Eksperimen & PBL dengan Scaffolding & X1 \\
\hline Kelas Kontrol & Konvensional & X2 \\
\hline
\end{tabular}

\section{HASIL DAN PEMBAHASAN}

Pengujian hipotesis dalam penelitian ini dilakukan dengan analisis Anova Dua Jalur (Two Way Anova). Uji hipotesis dilakukan untuk menetukan apakah hipotesis yang diajukkan diterima atau ditolak. hasil uji hipotesis menunjukkan bahwa nilai sig. $\left\langle 0,05\right.$ dan nilai $\mathrm{F}_{\text {hitung }}>$ $\mathrm{F}_{\text {tabel }}$. Dimana nilai $\mathrm{F}_{\text {tabel }}=4,01$. Hal ini dapat disimpulkan bahwa ada erbedaan motivasi dan pemahaman konsep fisika yang belajar menggunakan model pembelajaran Problem Based Learning berasis scaffolding dengan siswa yang belajar menggunakan model pembelajaran konvensional. Berdasarkan tabel 2 menunjukkan bahwa nilai sg $<0,05$ sehingga dapat disimpulkan bahwa ada interaksi model pembelajaran Problem Based Learning berbasis scaffolding dan motivasi belajar terhadap pemahaman konsep fisika.

\section{Motivasi Belajar}

Berdasarkan hasil penelitian bahwa ada pengaruh model pembelajaran Problem Based Learning melalui metode scaffolding terhadap motivasi belajar. Hal ini dapat dilihat dari uji Anova Dua Jalur (Two Way Anova) dengan menggunakan aplikasi SPSS di mana nilai sig < $0,05(0,021<0,05)$. Karena nilai sig $<0,05$ maka $\mathrm{H}_{0}$ ditolak. Artinya ada pengaruh model pembelajaran Problem Based Learning (PBL) melalui metode scaffolding terhadap motivasi belajar dengan siswa yang belajar menggunakan model pembelajaran konvensional. Hasil penelitian ini sejalan dengan penelitian (Ramlawati., Yunus., \& Insaini, 2017) dan Made (2018) menunjukkan bahwa ada pengaruh model pembelajaran Problem Based Learning melalui metode saffolding terhadap motivasi belajar siswa. Sehingga dapat disimpulkan bahwa model pembelajaran Problem Based Learning melalui metode scaffolding dapat meningkatkan motivasi belajar siswa. Data selengkapnya disajikkan pada Gambar 1.

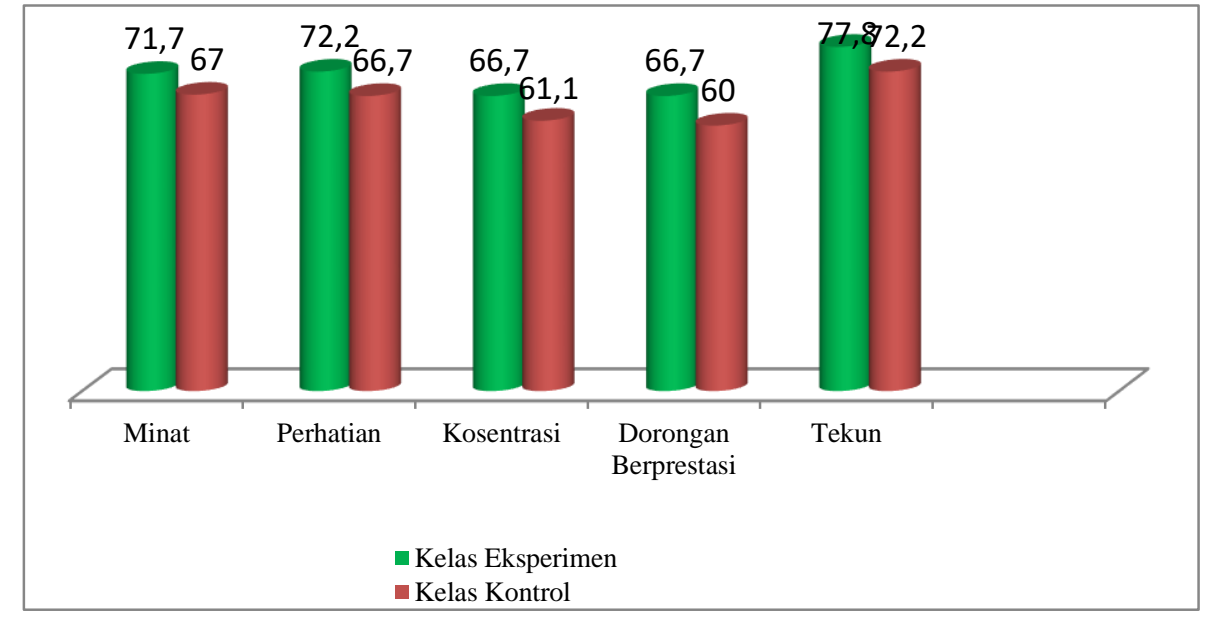

Gambar 1. Histogram Rata-Rata Motivasi Belajar 
Perbedaan masisng-masing indikator motivasi belajar dijelaskan sebagai berikut :

a. Minat

Minat siswa pada kelas eksperimen lebih tinggi dibandingkan minat siswa pada kelas kontrol. Indikator minat siswa dapat dikembangkan melalui tahap pertama model pembelajatran Problem Based Learning berbasis scaffolding yaitu orientasi siswa pada masalah. Minat siswa ada kelas eksperimen lebih tinggi dari pada kelas kontrol ini disebabkan karena pada kelas eksperimen guru memberikan orientasi permasalahan kepada peserta didik melalui pertanyaan dan berupa vidio dan gambar terkait tekanan hidrostatis dalam kehidupan sehari-hari. Guru memberikan pertanyaan-pertanyaan terkait peristiwa yang ditayangkan dalam bentuk vidio.

Contoh pertanyaan yang digunakan dalam model pembelajaran Problem Based Learning berbasis scaffolding dijelaskan sebagai berikut : anak-anak mengapa pada saat kalain menyelam dan berusaha menyelam lebih dalam apa yang dirasakan di telinga pada saat menyelam? Siswa memberikan jawaban, contoh jawaban yang diberikan oleh siswa adalah : telinga akan terasa sakit. Selanjutnya guru melanjutkan pertanyaan : mengapa telinga terasa sakit saat kamu menyelam terlalu dalam? Siswa merasa kesulitan memecahkan masalah tersebut sehingga guru memberikan scaffolding (bantuan) berupa contoh pertanyaan yang lain pertanyaanya adalah : anak-anak apakah kalian mempunyai bak penampung air di rumah? Siswa menjawab : ada Bu. Kemudian guru melanjutkan pertanyaan : mengapa tandon yang penuh dengan air, ketika keran dibuka air akan mengalir dengan deras? Siswa menjawab pertanyaan dari guru : karena adanya tekanan Bu.

Pemberian scaffolding atau bantuan ini dapat membangkitkan minat siswa untuk memecahkan masalah, sehingga masalah yang disajikkan daat dipecahkan sendiri oleh siswa. Kemudian guru memberikan pertanyaan berkaitan dengan cara memecahkan masalah. Anakanak untuk membuktikan engaruh kedalaman terhadap tekanan pada zat cair, maka paa yang akan kita lakukan? Siswa merasa kesulitan, kemudian guru memberikan scaffolding : Anakanak bagaimana kalau kita melubangi botol ini secara vertikal, kemudian kita masukkan air di dalamnya? Bagaimanakah tekanan yang akan terjadi pada ketiga lubang pada botol ini, apakah semakin ke bawah tekananya semakin besar ataukah semakin kebawah tekananya semakin kecil? Setelah diberikan scaffolding siswa mengerti bahwa untuk membuktikan pengaruh kedalaman terhadap tekana zat cair adalah dengan melakuakn kegiatan eksperimen yaitu melubangi botol secara vertikal. Kemudian guru bertanya berkaitan dengan alat dan bahan yang diperlukan dalam kegiatan eksperimen. Anak-anak alat dan bahan apa sajakah yang dierlukan dalam kegiatan eksperimen ini? Siswa menjawab : botol, paku, dan air Bu. Kemudian guru melanjutkan pertanyaan : anak-anak apakah alat dan bahan yang diperlukan hanya botol, paku dan air saja ? siswa menjawab : Ya Bu. Kemudian guru melanjutkan pertanyaan: untuk meutupi lubang pada botol sebelum diisi air agar airnya tidak keluar, kita menggunakan apa? Karena diberikan scaffolding siswa bisa menyebutkan alat dan bahan yang digunakan dalam melakukan eksperimen. Kemudian guru bertanya berkaitan denagn langkah-langkah dalam melakukan ekserimen. Anak-anak bagaimana langkah-langkah dalam melakukan eksperimen ini? Siswa menjawab : kita akan melubangi botol menggunakan paku kemudian diisi air. Kemudian guru melanjutkan pertanyaan : anak-anak untuk menetukan kedalaman pada botol apa yang akan kita lakuakan? Siswa menjawab : megukur ketinggian pada botol. Denagn diberikan scaffolding siswa bisa menjawab langkah-langkah apa yang akan dilakukan dalam eksperimen. Minat siswa juga dapat dilihat pada saat guru memberikan instruksi untuk duduk bersama kelompoknya masing-masing, dari enam kelompok yang terbentuk rata-rata siswa dalam kelompoknya masing-masing mengikuti instruksi dari guru dan hanay sedikit siswa yang tidak mengikuti 
instruksi dari guru. Kemudian minat siswa juga dapat dilihat pada saat melakukan diskusi kelompok. Pada saat diskusi kelompok sebagian besar siswa aktif meskipun ada sebagian kecil siswa yang tidak aktif. Hal ini terjadi karena ada beberapa siswa yang melakukan aktivitas lain.

Pada kelas kontrol penyebab dari rebdahnya minat belajar siswa adalah karena siswa tidak dihadapkan langsung pada masalah yang berkaitan dalam kehidupan sehari-hari. Hal ini menyebabkan kurangnya minat siswa untuk bertanya dan menjawab pertanyaan dari guru. Pada kelas kontrol pada saat guru menginstruksi siswa untuk duduk dalam kelompoknya masingmasing hanya sebagian kecil siswa yang menikuti instruksi dari guru sedangkan sebagian besar siswa tidak langsung merespon instruksi dari guru. Kemudian pada saat diskusi kelompok hanya sebagian kecil siswa saja yang aktif dalam diskusi kelompok sedangkan yang lainnya sibuk sendiri.

Berdasarkan hal di atas dapat disimpulkan bahwa minat belajar siswa pada kelas eksperimen lebih tinggi dibandingkan pada kelas kontrol. Dukungan minat belajar secara langsung dapat merubah perilaku belajar, dari yang tidak peduli menjadi lebih peduli (Lestari, 2013). Sehingga dengan minat belajar tersebut siswa akan bersedia meninggalkan kegiatan yang kurang mendukung encapaian tujuan belajar.

\section{b. Perhatian}

Indikator perhatian siswa diupayakan untuk dikembangkan pada tahap orientasi siswa pada masalah dan pada tahap membimbing penyelidikan individu maupun kelompok. Pada tahap ini peserta didik dilatih untuk mengoptimalkan perhatian mereka pada saat penyajian masalah sehingga mereka bisa menjawab pertanyaan yang disampaikan oleh guru. Perhatian siswa pada kelas eksperiemen lebih tinggi dibandingkan pada kelas kontrol. Hal ini dibuktikan dengan siswa pada kelas eksperimen lebih menunjukkan perhatiannya saat proses pembelajaran berlangsung. Pada kelas eksperimen sebagian besar siswa memperhatikan seluruh proses pembelajaran meskipun ada sedikit siswa yang tidak memperhatikan. Perhatian siswa dibuktikan dengan respon siswa ketika guru bertanya mengenai materi yang dijelaskan, siswa mampu menjawab meskipun diberikan scaffolding terlebih dahulu oleh guru. Contoh pertanyaan yang diberikan guru adalah : anak-anak menurut kalian apa yang dimaksud dengan tekanan? Siswa menjawab : tekanan hidrostatis adalah tekanan pada zat cair. Kemudian guru memberikan scaffolding yaitu: anak-anak tadi kalian menjawab bahwa tandon yang berisi air bisa mengeluarkan air dengan deras itu disebabkan karena adanya tekanan, berarti apa yang dimaksud dengan tekanan hidrostatis? Dengan diberikan scaffolding siswa bisa menjawab pertanyaan yang diberikan oleh guru. Hal ini membuktikan bahwa siswa memiliki perhatian pada saat proses pembelajaran berlangsung. Dan pada saat proses pembelajaran sebagian besar siswa tidak mengganggu jalannya proses pembelajaran, karena siswa memusatkan perhatiannya.

Berbeda halnya dengan kelas kontrol, pada kelas kontrol hanya sebagian kecil siswa yang memperhatikan seluruh proses pembelajaran. Hal ini terjadi karena siswa hanya mendengar ceramah dari guru. Proses pembelajaran seperti ini akan mengakibatkan siswa merasa jenuh sehingga siswa tidak memiliki perhatian mengikuti seluruh prose pembelajaran. Karena untuk menjamin hasil belajar yang baik, maka siswa harus mempunyai perhatian terhadap bahan pelajaran yang dipelajarinya, jika bahan pelajaran tidak menjadi perhatian siswa maka timbulah kebosanan, sehingga ia tidak suka lagi belajar (Slameto, 2015).

\section{c. Konsentrasi}

Konsentrasi siswa pada kelas eksperimen lebih baik dibandingkan dengan kelas kontrol. Pada kelas eksperimen siswa mengikuti seluruh proses pembelajaran samapai selesai meskipun sebagian kecil tidak terlibat. Indikator konsentrasi dapat dikembangkan melalui tahap ke tiga 
model pembelajaran Problem Based Learning berbasis scaffolding yaitu membimbing penyelidikan individu maupun kelompok. Berdasarkan penelitian yang dilakuakn sebagian besar siswa pada saat melakukan praktikum sangat berkosentrasi.

Pada saat melakukan praktikum siswa merasa kesulitan dalam menentukan kedalaman air pada botol. Ada beberapa siswa yang menyatakan bahwa kedalaman air pada nomor 3 adalah 15 $\mathrm{cm}$ dan yang pada nomor 1 adalah $5 \mathrm{~cm}$. Tetapi ada beberapa siswa yang menyatakan kedalaman air pada nomor 3 aadalah $5 \mathrm{~cm}$ dan yang pada nomor 1 adalah $15 \mathrm{~cm}$. Siswa menjawab seperti itu karena mereka kesulitan dalam mengukur kedalaman. Ada siswa yang mengukur kedalaman dari bawah dan ada siswa yang mengukur kedalaman dari atas. Sehingga guru memberikan scaffolding atau bantuan kepada siswa yang merasa kesulitan dalam menentukan kedalaman air pada botol yaitu dengan cara guru memberikan sebuah pertanyaan kepada siswa : anak-anak menurut kalian apa yang dimaksud dengan kedalaman? Siswa menjawab : jarak dari permukaan sampai ke dasar. Guru melanjutkan pertanyaan : berdasarkan kedalaman air pada botol ini untuk lubang nomor 1 memiliki kedalaman berapa? Semua siswa menjawab $5 \mathrm{~cm}$. Pemberian scaffolding ini dapat meningkatkan konsentrasi siswa untuk melakukan praktikum, sehingga pada saat praktikum siswa tidak terjadi kesalahan dalam memperoleh data.

Berbeda dengan kelas kontrol sebagian besar siswanya tidak menggunakan seluruh waktunya untuk proses pembelajaran. Hal ini diseabbkan karena pada kelas kontrol guru tidak memberikan araahn kepada peserta didik untuk terlibat secara aaktif, sehingga ssiwa merasa jenuh pada saat proses pembelajaarn sehingga mereka tidak kosentrasi mengikuti proses pembelajaran melainkan waktunya digunakan untuk kesibukannya nmasing-masing. Karena kesulitan anak untuk melakukan konsentrasi merupakan sumber penyebab timbulnya frustasi dan ketidakmampuan untuk berprestasi walaupun sebenarnya mereka merupakan aank yang cerdas dan berbakat (Petersen, 2004). Siswa yang memiliki konsentrasi akan dapat mengoptimalkan kemampuan siswa dalam merespon dan menginterprestasikan pelajaran yang sedang dipelajari sehingga akan berpengaruh pada prestasi belajar siswa.

\section{d. Dorongan Berprestasi}

Kegiatan yang mendukung indikator dorongan berprestasi adalah tahap ke empat model pembelajaran Problem Based Learning berbasis scaffolding yaitu mengembangkan dan menyajikkan hasil karya. Dorongan berprestasi pada kelas eksperimen lebih tinggi dibandingkan pada kelas kontrol. Hal ini terjadi karena siswa pada kelas eksperimen memiliki semangat untuk ikut serta dalam memecahkan masalah pada LKS. Pada saat memecahkan masalah pada LKS siswa yang merasa kesulitan diberikan scaffolding oleh guru. Kesulitan yang dialami siswa adalah pertanyaan yang berkaitan dengan alasan mengapa jika botol diberi tutup pancaran airnya tidak sekuat jika dibandingkan tanpa tutup botol. Kemudian guru memberikan scaffolding kepada siswa. Dengan diberikan sacffolding siswa bisa menjawab alasan mengapa jika botol diberi tutup pancaran aiarnya tidak sekuat jika tanpa tutup.

Berbeda dengan kelas kontrol hanya sebagian kecil siswa yang ikut serta dalam memecahkan masalah pada LKS. Hal ini dibuktikan pada keas kontrol siswa yang ikut serta dalam memecahkan masalah hanay 3 orang saja, sedangkan yang lainnya hanya diam saja. Hal ini terjadi karena siswa pada kelas kontrol tidak diberikan scaffolding oleh guru, sehingga siswa tidak memiliki semangat untuk belajar. Kondisi demikian akan mengakibatkan siswa tidak ikut serta dalam memecahkan amsaalh karena mereka tidak meiliki semangat. Karena siswa yang semangat akan akan dengan mudah memahami materi yang diberikan sehingga mereka ikut serta dalam memecahkan masalah yang disajikkan. Siswa yang memiliki dorongan berprestasi akan akan menunjukkan adanaya perjuangan untuk mencapai prestasi belajar yang lebih baik. 
Sehingga dorongan berprestasi sangat penting bagi siswa karena sebagai pendorong untuk mempengaruhi siakp apa yang seharusnya anak didik ambil dalam rangka belajar (Djmarah, 2002).

\section{e. Ketekunan}

Ketekunan siswa pada pada kelas eksperimen lebih tinggi dibandingkan pada kelas kontrol. Tahap yang mendukung indikator ini adalah tahap ke empat model pembelajaran Problem Based Learning berbasis scaffolding yaitu mengembangkan dan menyajikkan hasil karya. Berdasarkan hasil penelitian yang dialkuakn pada kelas eksperimen sebagian besar siswa mengumpulkan tugas tepat waktu. Hal ini terjadi karena pada kelas ekserimen pada saat melakukan diskusi kelompok siswa yang merasa kesulitan diberikan scaffolding oleh guru. Hal ini terjadi pula karena pada saat melakuakan diskusi kelompok siswa yang aktif mengerjakan 34 orang, sehingga mereka cepat menyelesaikan tugas mereka dan mengumpulkannya tepat waktu.

Berbeda halnya dengan kelas kontrol hanya sebagian kecil siswa yang menumpulkan tugas tepat wkatu. Hal ini terjadi karena pada saat melakuakn diskusi kelompok siswa tidak diberikan scaffolding. Kondisi demikian akan mengakibatkan siswa tidak memiliki antusias untuk menyelesaikan tugas merekasehingga tidak bisa mengumpulkanya tepat waktu. Hal ini terjadi pula karena pada saat melakukan diskusi kelompok yang aktif hanya 2-3 orang saja. Kondisi demikian akanmengakibatkan siswa tidak cepat menyelesaiakn tugas mereka. Karena rendahnya hasil belajar siswa disebabkan oleh banyak faktor, satu diantaranya adalaha ketekunan (Aritontang, 2008).

Berdasarkan penelitian pada kelas eksperimen dan kelas kontrol diketahui bahwa masingmasing indikator motivasi belajar pada kelas eksperimen lebih tinggi dibandingkan dengan indikator motivasi belajar pada kelas kontrol. Oleh karena itu, berlandaskan pada penjelasan keterlaksanaan pembelajaarn serta hasil penelitian maka untik meningkatkan moivasi belajar siswa dapat dilakukan dengan melalui penerapan model pembelajaran Problem Based Learning berbasis scaffolding.

\section{Pemahaman Konsep Fisika}

Berdasarkan hasil penelitian bahwa ada pengaruh model pembelajaran Problem Based Learning (PBL) melalui metode Scaffolding terhadap pemahaman konsep fisika. Hal ini dapat dilihat dari hasil uji Anova Dua Jalur (Two Way Anova) dengan menggunakan SPSS di mana nilai sig < 0,05 $(0,000<0,05)$. Karena nilai sig < 0,05 maka $\mathrm{H}_{0}$ ditolak. Artinya ada pengaruh model pembelajaran Problem Based Learning (PBL) melalui metode Scaffolding terhadap pemahaman konsep fisika dengan siswa yang belajar menggunakan model pembelajaran konvensional. Hal ini dapat dilihat pada Gambar 2.

Hasil uji statistik juga didukung oleh nilai rata-rata siswa setelah diberikan tes pemahman konsep. Hasil tes pemahaman konsep menunjukkan bahwa siswa yang belajar dengan menggunakan model pembelajaran Problem Based Learning melalui metode Scafolding memperoleh nilai rata-rata adalah 79 dan siswa yang belajar menggunakan model pembelajaran konvensional memperoleh nilai nilai rata-rata adalah 70,5. Hal ini menunjukkan bahwa nilai rata-rata pemahaman konsep siswa pada kelas eksperimen lebih tinggi daripada siswa pada kelas kontrol. Artinya pemahaman konsep yang dimiliki siswa yang belajar menggunakan model pembelajaran Problem Based Learning berbasis Scaffolding lebih baik dari siswa yang belajar menggunakan model pembelajaran konvensional. 


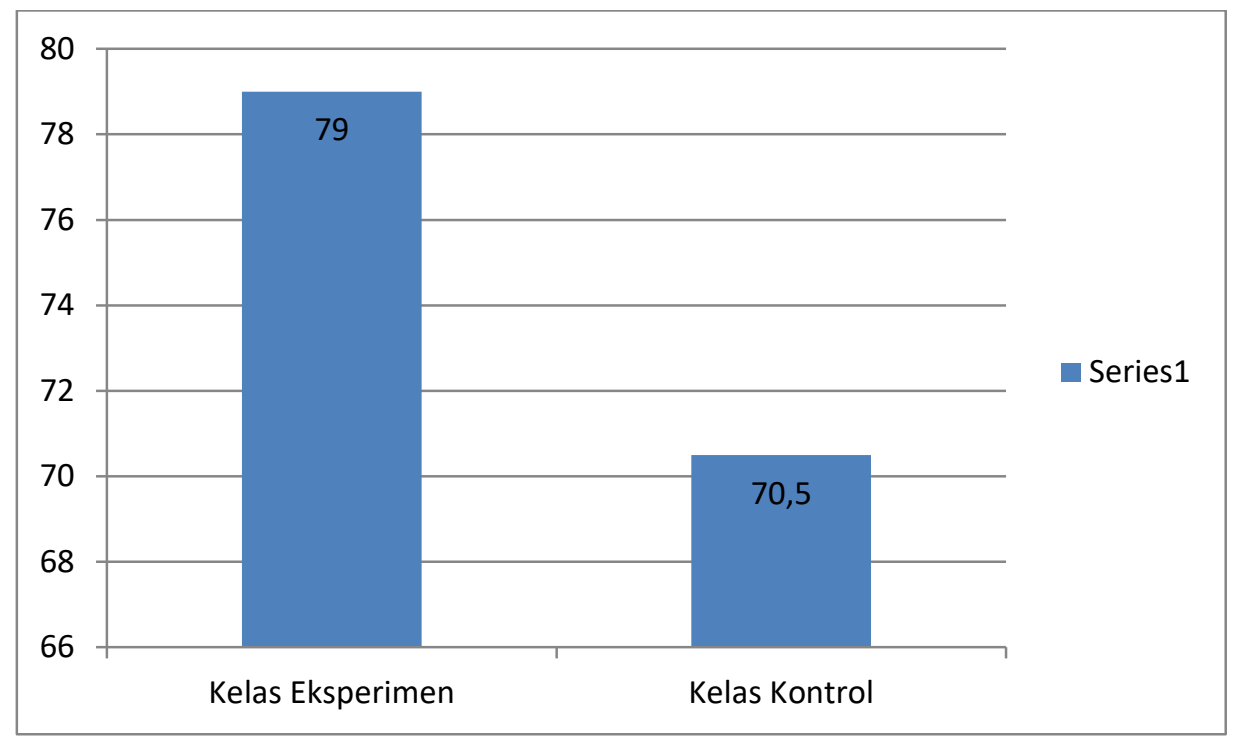

Gambar 2 Histogram Rata-Rata Pemahaman konsep

Hasil penelitian ini sejalan dengan hasil penelitian (Kono., Mamu., \& Tangge, 2016) yang membuktikan bahwa terdapat pengaruh model pembelajaran Problem Based Learning (PBL) terhadap pemahaman konsep. Selain itu penelitian yang telah dilakukan oleh (Nicke.,\& Irwan, 2014) menunjukkan bahwa metode Scaffolding dalam pembelajaran dapat meningkatkan kemampuan pemahaman konsep. Sehingga dapat disimpulkan bahwa penggunaan model pembelajaran Problem Based Learning melalui metode scaffolding dapat meningkatkan pemahaman konsep.

Model pembelajaran yang digunakan pada kelas eksperimen adalah model pembelajaran Problem Based Learning berbasis Scaffolding. Kegiatan pada kelas eksperimen pada tahap pertama yaitu orientasi siswa pada masalah. Pada tahap ini guru memberikan orientasi permasalahan kepada peserta didik melalui pertanyaan dan berupa vidio dan gambar terkait tekanan hidrostatis dalam kehidupan sehari-hari. Kemudian guru memberikan pertanyaan-pertanyaan terkait peristiwa yang ditayangkan dalam bentuk vidio. Guru memberikan scaffolding kepada siswa yang merasa kesulitan. Dengan diberikan Scaffolding siswa mampu memecahkan sendiri masalah yang disajikan, sehingga siswa mampu memahami konsep fisika berdasarkan masalah yang disajikan.

Berbeda dengan kelas kontrol, pada kelas kontrol dimulai dengan guru menyampaikan beberapa pertanyaan tentang tekanan hidrostatis dan kemudian penyampaian tujuan pembelajaran. Pada saat guru memberikan pertanyaan siswa tidak bisa menjawab. Hal ini terjadi karena pada kelas kontrol siswa tidak dihadapkan pada masalah sehingga mereka tidak bisa menjawab pertanyaan dari guru karena pemahaman siswa kurang. Tahap kedua yaitu mengorganisasi peserta didik untuk belajar. Pada tahap ini siswa menyiapkan alat dan bahan untuk melakukan percobaan serta merancang cara menyelesaikan masalah. Guru memberikan scaffolding kepada siswa yang merasa kesulitan. Dengan diberikan sacaffolding siswa yang merasa kesulitan dapat menyelesaikan dan memahami konsep masalah yang diberikan. Tahap ketiga yaitu membimbing penyelidikan individu maupun kelompok. Pada saat melakukan praktikum siswa merasa kesulitan dalam melakukan praktikum, kemudian guru memberikan scaffolding kepada siswa. Dengan diberikan Scaffolding siswa bisa mendapatkan data yang maksimal sehingga mereka bisa memahami konsep fisika berdasarkan praktikum yang telah dilakukan. Tahap keempat yaitu mengembangkan dan menyajikkan hasil karya. Guru meminta siswa untuk mempresentasikan hasil diskusi kelompok dan meminta tanggapan kelompok lain berdasarkan pemahaman mereka. Dalam diskusi kelompok siswa akan bertukar pendapat dan 
ide, sehingga peserta didik lebih bergairah dan semangat dalam belajar. Siswa yang semangat dalam belajar akan dengan mudah memahami konsep fisika. Selanjutnya tahap kelima yaitu menganalisis dan mengevaluasi proses pemecahan masalah. Pada tahap ini guru membantu siswa melakukan refleksi atau evaluasi proses dan hasil penyelidikan, sedangkan siswa memperhatikan penjelasan guru. Hasil dari evaluasi tersebut, siswa dapat memahami konsep fisika dan mengetahui jawaban yang paling tepat berkaitan dengan masalah yang disajikan.

Hasil penelitian pada kelas eksperimen menghasilkan pembelajaran yang lebih baik dibandingkan dengan kelas kontrol. Hal ini disebabkan karena pada kelas eksperimen yang menggunakan model pembelajaran Problem Based Learning berbasis scaffolding memiliki tahapan-tahapan yang kompleks yaitu mengorientasikan siswa pada masalah, mengorganisasikan siswa untuk belajar, membimbing penyelidikan individu maupun kelompok, mengembangkan dan menyajikkan hasil karya, serta menganalisis dan mengevaluasi proses pemecahan masalah. Pembelajaran yang menggunakan pendekatan berupa masalah dalam kehidupan sehari-hari sebagai konteks bagi siswa untuk melakukan aktivitasnya dalam memecahkan permasalahan yang disajikkan sehingga siswa dapat memahai konsep-konsep dari materi yang dipelajari.

Berbeda dengan kelas kontrol yang menggunakan model pembelajaran langsung. Pada model pembelajaran langsung tidak memiliki tahapan-tahapan yang kompleks seperti pada model pembelajaran Problem Based Learning. Dalam pembelajaran langsung, pembelajaran lebih berpusat pada guru dan guru sebagai satu-satunya sumber belajar. Pembelajaran seperti ini akan membuat siswa merasa jenuh sehingga siswa meras sulit memahami materi yang diberikan.

Selain didukung oleh model pembelajaran yang dipilih, keberhasilan dari suatu pembelajaran juga tergantung dari bantuan yang diberikan oleh pendidik. Bantuan yang dimaksud adalah Scaffolding. Penerapan model pembelajaran Problem Based Learning melalui metode Scaffolding merupakan model pembelajaran yang melibatkan siswa secara aktif (student centerred). Dalam hal ini siswa dituntut untuk terlibat aktif memecahkan suatu masalah melaui proses pembelajaran yang disertai dengan metode scaffolding berupa bimbingan atau pemberi bantuan kepada siswa yang mengalami kesulitan. Contohnya pada saat siswa kesulitan dalam menghubungkan masalah dengan konsep fisika. Pada saat siswa merasa kesulitan, guru memberikan Scaffolding berupa contoh pertanyaan lain yang lebih sederhana sehingga siswa bisa mengkaitkan masalah dengan konsep fisika. Karena dengan memberikan Scaffolding siswa sangat antusis untuk menyelesaikan masalah dalam proses pembelajaran berdasarkan bantuan yang diberikan. Siswa yang memiliki antusias untuk belajar akan memberikan pengaruh yang besar terhadap kemampuan kognitif siswa karena siswa yang memiliki antusias untuk belajar akan menanggapi pembelajaran fisika dengan positif sehingga apapun yang dijelaskan terkait konsep-konsep fisika akan lebih mudah dipahami. Karena salah satu faktor penting yang mempengaruhi pemahaman konsep fisika siswa adalah model pembelajaran yang digunakan selama proses pembelajaran berlangsung (Restami., Suma., \& Pujani, 2013). Jika model pembelajaran yang diterapkan mampu menarik dan tidak menimbulkan kejenuhan siswa, maka siswa akan lebih mudah menyerap dan memahami materi yang diberikan lebih khusus pemahaman siswa terhadap konsep-konsep dari materi tersebut.

\section{Interaksi Model Antara Model Pembelajaran Problem Based Learning Melalui Metode Scaffolding Dan Motivasi Belajar Terhadap Pemahaman Konsep Fisika Siswa}

Berdasarkan hasil analisis data uji statistik diperoleh bahwa terdapat interaksi antara model pembelajaran Problem Based Learning melalui metode Scaffolding terhadap motivasi belajar dan pemahaman konsep Fisika siswa. Hal ini dibuktikan dengan hasil analisis yaitu nilai 
sig $<0,05(0,012<0,05)$. Hasil penelitian ini sejalan dengan teori yang dikemukan oleh MC Demort dalam (Eggen, 2012) yang menyatakan bahwa antara motivasi dan pembelajaran terdapat korelasi yang tinggi. Jika ada motivasi belajar maka hasil belajar pun akan optimal (Sardiman, 2007).

Hasil penelitian ini sejalan dengan penelitian (Febrianti, 2013) bahwa motivasi belajar berpengaruh pada pemahaman konsep fisika. Artinya siswa yang mempunyai motivasi belajar tinggi memiliki pemahaman konsep yang tinggi dibandingkan dengan siswa yang mempunyai motivasi rendah. Hal ini dibuktikan dengan hasil rata-rata nilai motivasi belajar pada kelas eksperimen adalah 74,67 dan nilai rata-rata pemahaman konsep adalah 79. Sedangkan pada kelas kontrol memiliki nilai rata-rata motivasi belajar adalah 68,17 dan nilai rata-rata pemahaman konsep adalah 70,5. Sehingga dapat disimpulkan bahwa jika siswa memiliki motivasi belajar yang tinggi maka siswa tersebut akan lebih mudah dalam menanggapi dan memahami materi yang disampaikan oleh guru.

Sejalan dengan penelitian yang dilakukan oleh (Sari, 2010) bahwa siswa yang mempunyai motivasi belajar tinggi akan memberikan dampak yang besar terhadap kemampuan kognitif fisika siswa, karena siswa yang memiliki motivasi yang tinggi akan dengan mudah memahami konsep-konsep fisika. Jadi motivasi memegang peranan penting dalam memberikan semangat belajar. Karena siswa yang memiliki semangat untuk belajar akan mencapai tujuan pembelajaran yang maksimal. Demikian juga hasil penelitian yang dilakukan oleh (Fitriani, 2017) bahwa hasil belajar siswa yang memiliki motivasi belajar tinggi akan selalu lebih baik dari pada hasil belajar siswa yang memiliki motivasi belajar rendah.

Modifikasi model PBL dengan Scaffolding dapat meningkatkan motivasi siswa karena dengan memberikan Scaffolding siswa akan termotivasi untuk belajar. Siswa yang termotivasi untuk belajar akan dengan mudah memahami konsep-konsep. Sehingga dapat disimpulkan bahwa semakin menarik model maupun metode pembelajaran yang digunakan maka semakin tinggi motivasi belajar dan semakin tinggi pula pemahamannya terhadap materi yang disampaikan.

\section{PENUTUP}

Berdasarkan data hasil analisis dari penelitian yang telah dilaksanakan, dapat disimpulkan bahwa (1) Terdapat perbedaan motivasi belajar siswa yang belajar dengan menggunakan model pembelajaran Problem Based Learning (PBL) melalui metode scaffolding dengan siswa yang belajar menggunakan model pembelajaran konvensional, (2) terdapat perbedaan pemahaman konsep fisika antara siswa yang belajar menggunakan model pembelajaran Problem Based Learning melalui metode Scaffolding dengan siswa yang belajar menggunakan model pembelajaran konvensional, (3) terdapat interaksi antara model pembelajaran Problem Based Learning (PBL) melalui metode scaffolding dan motivasi belajar terhadap pemahaman konsep fisika siswa.

\section{Saran}

Saran yang dapat diberikan adalah bagi guru mata pelajaran Fisika hendaknya menggunakan model pembelajaran Problem Based Learning (PBL) melalui metode scaffolding supaya tujuan pembelajaran dapat tercapai secara maksimal.

\section{DAFTAR PUSTAKA}

Akinoglu, O., \& Tandogan, R. O. (2007). The effect of problem-based active learning in science educationon students academic achievement, attitude and concept learning. Eurasia Jou 
rnal Of Mathematics, Science and Technology Education., 3(1), 71-81. Retrieved from http://www.ejmste.com/v3n1/EJMSTE v3n1.

Aritonang, K. T. (2008). Minat dan Motivasi dalam Meningkatkan Hasil Belajara Siswa. Jurnal Pendidikan Penabur, 1(10), 11-21. Retrieved from http://www.bpkpenabur.or.id

Djmarah. (2002). Strategi Belajar Mengajar. Jakarta: Rineka Cipta.

Eggen, P. \& D. K. (2012). Strategi dan Model Pembelajaran: Mengajarkan Konten dan Keterampilan berpikir. Jakarta: PT Indeks Permata Putra Media.

Febrianti. (2013). Pengaruh Motivasi Belajar Dan Keterampilan Proses Sains Terhadap Pemahaman Konsep Fisika. Online. Retrieved from https://www.neliti.com/id/publicati ons/116268/pengaruh-motivasi-belajar-dan-keterampilan-proses-sains-terhadappemahaman-konsep

Fitriani, M. (2017). Pengaruh Model Problem Based Learning Terhadap Motivasi Belajar Sistem

Koordinasi Pada Siswa Di SMA Negeri 2 Bantaeng. Jurnal Biotek, 5(1), 228-239. Retri eved from http://journal.uinalauddin.ac.id/index.php/biotek/article/viewFile/3460/3253

Kono,R., Mamu,H.D., \& Tangge, L. N. (2016). Pengaruh Model Problem Based Learning (Pbl) Terhadap Pemahaman Konsep Biologi Dan Keterampilan Berpikir Kritis Siswa Tentang Ekosistem Dan Lingkungan Di Kelas X Sma Negeri 1 Sigi. Jurnal Sains DanTeknologi Tadulako, 5(1), 28-38. Retrieved from http://jurnal.untad.ac.id/jurnal/index.php/JSTT/ar ticle/download/6958/5595

Krisnawati, A. (2009). Penerapan Pembelajaran kooperatif Model Numbered Heads Together (NHT) Untuk MeningkatkanMotivasi dan Hasil Belajar Siswa Kelas VIII-H SMP Neger i 1 Watulimo Trenggalek. Online. Retrieved from http://fisika.um.ac.id/abstrak skripsi mahasiswa/306 penerapan pembelajaran-kooperatifmodel numbered heads together nht untukmeningkatkanmotivasi dan hasil belajar siswakelasviii h smp negeri 1watulimo tre nggalek.html

Lestari, I. (2013). Pengaruh waktu belajar dan minat belajar terhadap hasil belajar matematika. Jurnal Formatif, 3(2), 115-125. Retrieved from https://www.neliti.com/id/publications/ 234843/pengaruh-waktu-belajar-dan-minat-belajar-terhadap-hasil-belajar-matematika

Mamin, R. (2008). Penerapan Metode Pembelajaran Scaffolding Pada Pokok Bahasan Sistem Periodik Unsur. Jurnal Chemica, 10(2), 55-60. Retrieved from http://download.garuda.r istekdikti.go.id/article.php?article $=57819 \& v a l=4338 \&$ title=Penerapan Metode Pembelajaran Scaffolding Pada Pokok Bahasan Sistem Periodik Unsur

Petersen, L. (2004). Bagaimana Memotivasi Anak Belajar. Terjemahan oleh Ismail Isdito. Jakarta: Grasindo.

Rahman, N.A. (2004). Efektivitas penggunaan metode inteligensi ganda dalam proses pembelajaran fisika di SMU. Jurnal Penelitian dan Evaluasi Pendidikan, 6(1),72-87.

Ramlawati.,Yunus,S.R., \& Insaini, A. (2017). Pengaruh Model PBL (Problem Based Learning) terhadap Motivasi dan Hasil Belajar IPA Peserta Didik. Jurnal Sainsmat, 1(1), 1-14. Ret rieved from http://ojs.unm.ac.id/sainsmat/article/download/6451/3684

Restami, M. P., Suma, K., \& Pujani, M. (2013). Pengaruh Model pembelajaran POE (PredictObserve explaint) Terhadap Pemahaman Konsep Fisika Dan Sikap Ilmiah Dari Gaya Belajar Siswa. E Journal Program PascasarjanaUniversitas Peendidikan Ganesh $a, 3,1 \_14$. Retrieved from http://oldpasca.undiksha.ac.id/e-journal/index.php/jurnal_ipa /article/view/716\%0A\%0A.

Sardiman. (2007). Interaksi \& Motivasi Belajar Mengajar. Jakarta: PT Rajagravindo Persada. 
Sardiman. (2010). Interaksi dan Motivasi Belajar Mengajar. Jakarta: PT Rajagrafindo Persada.

Slameto. (2015). Belajar dan Faktor-Faktor yang Mempengaruhi. Jakarta: Rineka Cipta.

Slavin, R. E. (2009). Psikologi Pendidikan. Jakarta: Indeks.

Trianto. (2011). Model Pembelajaran Teradu. Jakarta: Bumi AKsara.

Umrotun. (2012). Peningkatan Pemahaman Konsep Optik Melalui Teknik Inkuiri Terbimbing Peserta Didik Kelas VIII Semester Genap Tahun Ajaran 2011/2012. Jurnal Penelitian Pembelajaran Fisika, 3(1),74-82

Yadav, A., Subedi, D., Lunberg, M. A., \& Bunting, C. F. (2011). Problem based Learning: Influence on Students' Learning in an Electrical Engineering Course. Journal of Engineering Education, 1(2), 253-280. Retrieved from https://onlinelibrary.wiley.com/d oi/10.1002/j.2168-9830.2011.tb00013 